\title{
PIK3C2B Gene
}

National Cancer Institute

\section{Source}

National Cancer Institute. PIK3C2B Gene. NCI Thesaurus. Code C102942.

This gene is involved in the metabolism of phosphoinositol. 